\title{
Collaborative Versus Prescriptive Legislating and Rulemaking: A CaSe Study of the Driver's License Provisions in the REAL ID Act of 2005
}

\section{By Susan E. Randolph}

Abstract: The terrorist attacks of September 11, 2001 and America's engagement in the Global War on Terror have added urgency to long-standing Congressional efforts to strengthen the country's system for establishing personal identification. Randolph examines the REAL ID Act of 2005, which legislates uniform requirements.for state drivers' licenses. She describes the way the REAL ID Act became law and is being implemented by the executive branch and outlines the objections of state and local government officials to its driver's license provisions.

\section{INTRODUCTION}

Fraudulent identification documents facilitated the free movement of the terrorists who attacked the United States on September 11, 2001 (National Commission 2004, 390). These attacks and the threat of future terrorist attacks have added urgency to ongoing Congressional efforts to strengthen the country's system for establishing personal identification. Because of the political challenges to instituting a federally-administered national ID, Congress has focused on standardizing the state-issued driver's license. In 2005, Congress passed the REAL ID Act, which prescribes uniform requirements for state driver's licenses that are acceptable for federal identification purposes. ${ }^{1}$ In the act, Congress directed that the Secretary of Homeland Security (DHS) issue regulations to standardize the driver's license using a form of rulemaking that provides the public only a limited opportunity to participate in the law's implementation.

Susan Randolph will graduate in May 2007 as the Honor Graduate from The George Washington University Master of Public Administration program. She holds a B.A. with distinction and honors in German from the University of Michigan and an M.L.S. from the University of Maryland. She is currently a special assistant in the Office of Fraud Prevention Programs at the U.S. Department of State.
The REAL ID Act is controversial. Its many critics challenge the legitimacy of the law based on both substance and process. Federalism advocates, for example, contend that the REAL ID Act's driver's license provisions impinge on state sovereignty and create insurmountable implementation problems. They object to the House Republican leadership's decision to block a full, bi-partisan discussion of the bill's merits. They oppose the repeal of the driver's license provisions of the Intelligence Reform and Terrorism Prevention Act of 2004, which allowed for more input from stakeholders through an executive branch rulemaking process called negotiated rulemaking. While state and local government officials support the goal of driver's license standardization-securer personal identification documents-opposition to the REAL ID Act at the state government level is almost universal.

The Secretary of Homeland Security has only recently issued proposed regulations to implement the act and the country's system of personal identification is still insecure. The history of the REAL ID Act suggests that a less prescriptive and more collaborative approach, such as that exemplified by the Intelligence Reform and Terrorism Prevention Act, might be more likely to produce the secure system of personal identification that the country needs.

The author would like to thank Professors Jed Kee and Kathy Newcomer for their encouragement during the writing of this article. 


\section{Drtver's License Provisions of THE REAL ID ACT OF 2005}

The driver's license provisions of the REAL ID Act, which will take effect on May 11, 2008, appear in Title II, Division B of the Emergency Supplemental Appropriations Act for Defense, the Global War on Terror, and Tsunami Relief, 2005 (Public Law 109-13, 49 U.S.C. 30301 et. sec.). A summary of the law's sections, based on the conference report, follows (U.S. Congress Congressional Record 2005c).

Section 202 of Title II prescribes minimum standards for the driver's license document. The law applies only to licenses acceptable to federal government agencies as identification. ${ }^{2}$ However, state governments must adopt the standards and alter any conflicting state law if the license is to be used as identification for federal purposes. The standards require that the driver's license display full legal name, date of birth, gender, traceable number, digital photograph, principal residence, and signature; employ a standard digital technology that facilitates information exchange; and contain security features to prevent identity fraud. A driver's license or identity card not meeting these standards must have a unique design or color and be clearly marked as unacceptable for federal purposes.

Section 202 also details standards for issuing the driver's license. A temporary license or identity card must expire on the date the non-citizen applicant's authorized stay in the United States ends. A citizen's license must be subject to renewal every eight years. Before a state issues a license, an applicant must present a minimum of five identifying documents, including proof of legal presence in the United States. States must verify the validity of each document and also establish a procedure for verifying the information of renewing applicants. States must use digital technology to store identity source documents. Each state must also maintain and make available electronically to other states a database that contains all the data that appear on the driver's license or identity card and the driving history of its owner. In order to reduce fraud, states must train employees to recognize fraudulent documentation, ensure the physical security of the locations and materials used in the production of driver's licenses and identity cards, obtain a security clearance for each employee who produces these documents, and make a digital facial image of each applicant, whether or not the state issues the license or identity card.

Section 203 requires that the Secretary of Homeland Security enter into the approptiate aviation security database information about individuals convicted of using a false driver's license at an airport.

Section 204 authorizes the Secretary of Homeland Security to make grants during fiscal years 2005-2009 to assist states in conforming to the minimum standards for driver's licenses and identity cards.

Section 205 authorizes the Secretary of Homeland Security, in consultation with the Secretary of Transportation and the states, to issue regulations. It prohibits the Secretary from engaging in any form of rulemaking other than the conventional procedure for giving regulatory notice.

Section 206 repeals the driver's license provisions of the Intelligence Reform and Terrotism Prevention Act of 2004.

\section{Pre-9/11 Congressional Action}

\section{on Personal Identification}

One approach to developing a secure system for personal identification would be to require a federallyadministered national ID. This approach has influential critics, however Former Speaker of the House of Representatives Newt Gingrich has observed that "the people most opposed to a national ID card are dramatically more passionate than the people who have some vague general support for a national ID card.... If we go down that toad, it's a dead end. It won't happen" (U.S. Congress House 2002, 50). Critics of a national ID include privacy groups such as the Electronic Privacy Information Center and civil liberties groups that range on the political spectrum from the liberal American Civil Liberties Union to the conservative Eagle Forum.

The opposition to a national ID reflects the fear of many Americans, dating from the founding of the Republic, that a strong central government might 
exercise tyrannical control over its citizens. The separation of powers principle discussed by James Madison in The Fedleralist essays addresses this fear (Hamilton, Jay, and Madison 2001): The Founders saw separation of powers and a federal system of government, also discussed in The Federalist, as bulwarks against a tyrannical central government.

More recently, public wariness about ID initiatives contributed to the abandonment of a 1965 Bureau of the Budget proposal for what would have been the federal government's first comprehensive databank of information on citizens, the National Data Center (Garfinkel 2000,14). The threat of terrorism only briefly diminished resistance to a national ID. Although a Harris poll taken immediately after the September 11 terrorist attacks found that 68 percent of Americans favored one, public support declined swiftly and to such an extent that a poll taken by the Gartner Group less than a year later found only 26 percent of Americans in favor of a national ID (Civil 2005).

Public opposition has compelled most legislators to disavow a desire to create a federally-administered national ID. The Congressional Reseatch Service noted that "prior to $9 / 11$, legislation aimed at discouraging national standards for identification documents had gained bipartisan support and was thought likely to pass" [emphasis added] (Garcia, Lee, and Tatelman 2005, 38). Indeed, House Judiciary Committee Chairman F. James Sensenbrenner, Jt. (R-WI) represented the driver's license provisions of the REAL ID Act as "the best antidote to a national identification card that we possibly can have" (Newsmaker 2005).

Because a federally-administered national ID is politically unpopular, policymakers eager to strengthen the country's personal identification system have concentrated on correcting weaknesses in the stateadministered driver's license, of which there are 240 variations (Grow 2003). With the Commercial Motor Vehicle Safety Act of 1986, Congress standardized the driver's license for interstate commercial drivers in order to deal with scofflaw truck drivers who applied for and received drivers' licenses from multiple states (Kernell and Jacobson 2003, 82). Congress also set standards for the driver's license in Section 656 of the Illegal Immigration Reform and Immigrant Responsibility Act of 1996, as part of efforts since the late 1970 s to improve the security of identity and work authorization documents (U.S. Congress House 2002, 26).

\section{First Post-9/11}

\section{Congressional Attempt to Regulate the Driver's}

\section{LICENSE}

The terrorist attacks of September 11, 2001 reinforced the resolve of the country's policymakers to develop a secure system for personal identification. In a 2002 Office of Homeland Security report, the Bush Administration called for the development of minimum standards for the driver's license (U.S. Office of Homeland 2002). The National Commission on Terrorist Attacks Upon the United States recommended that "the federal government...set standards for the issuance of birth certificates and sources of identification, such as drivers licenses," asserting that "secure identification should begin in the United States" (National Commission 2004, 390). As the Commission noted in its 2004 final report, all but one of the $9 / 11$ hijackers acquired some form of U.S identification document, some by fraud. Acquisition of these forms of identification would have assisted them in boarding commercial flights, renting cars, and other necessary activities (National Commission 2004, 390).

Indeed, the 19 hijackers who participated in the attack on the United States had accumulated 63 driver's licenses and Mohatnmed Atta, the most notorious hijacker, had eight (Tancredo 2004, H 11004; Clyne 2005).

Congtess implemented the 9/11 Commission's recommendation on the driver's license in the Intelligence Reform and 'Terrorism Prevention Act of 2004. ${ }^{3}$ It delegated authority to the Secretary of Transportation, in consultation with the Secretary of Homeland Security, to develop minimum standards regarding the information and security features on and. the process for issuing state driver's licenses and personal identification cards that would be acceptable to a 
federal agency for official purposes. It directed the Secretary of Transportation to use negotiated rulemaking, a form of rulemaking that allows for the significant involvement of stakeholders in the development of regulations. Congress also directed that some standard setting be left to the discretion of state governments. For example, it prohibited a requirement of a single uniform design. It also prohibited infringement on the right of states to determine the categories of individuals, such as illegal immigrants, eligible to obtain identification documents (Tatelman 2005).

The Intelligence Reform and Terrorism Prevention Act became Public Law 108-458 on December 17, 2004, after receiving bipartisan approval in the House with a vote of 336-75 and in the Senate with a vote of 89-2 (U.S. Congress House 2004, H 11028; U.S. Congress Senate 2004, S 12010). However, the conference committee deliberations preceding its approval had been contentious. Congress convened the conference committee to reconcile differences between the House bill (H.R. 10) and the Senate bill (S. 2845). The two bills differed in their approach to driver's license standardization: the Senate delegated authority to the executive branch to develop standards regarding the driver's license, whereas the House prescribed the standards (H.R. 10 2004). The House bill also contained language blocking the issuance of a driver's license to an illegal immigrant. Only about half of the states require that a driver's license applicant demonstrate lawful presence in the United States (Smith 2005, CRS-2). This language was opposed by most Democrats and did not appear in the Senate bill. The House bill's sponsor, Representative Sensenbrenner ( $R$ WI), and the members of the Congressional Immigration Reform Caucus led by Representative Tom Tancredo (R-CO) maintained that the immigration provisions were "essential to the war on terrorism," while its Democratic opponents argued that the provisions were "extraneous" and unfair to Hispanic immigrants" (Dlouhy 2005b, Kady 2004).

In order to ensure Senate Democratic support for and passage of the Intelligence Reform and Terrorism Prevention Act, the members of the conference committee adopted the Senate bill as the basis for their reconciliation work and rejected the language in the House bill on driver's license standards (Putrich 2005).
Rep. Sensenbrenner responded with a fierce denunciation:

The language in the conference report is worse than the current law, and it practically invites terrorists to come into the country and to apply for these critical identification documents. There is no enforcement or certification at the national level. There is no expiration of the licenses when the visas expire. There is no datasharing between the States. And any State can simply walk away from the few requirements that are in the bill. That does not sound like driver's license reform to me. Rather, it sounds like a recipe for disaster, the same kind of disaster that occurred on $9 / 11$ (Sensenbrenner 2004, H 10998).

Asking how legislators could face grieving survivors in the event of a future tertorist attack were Congress not to approve the language in the House bill, Rep. Sensenbrenner vowed to bring up his bill's driver's license provisions "relentlessly" and "not rest" until they were enacted into law (Sensenbrenner 2004, H 10998).

The House Republican leadership, recognizing the passion of the immigration provisions' supporters and fearing that they would impede expeditious passage of the Intelligence Reform and Terrorism Prevention Act, pledged to attach the House bill's driver's license language to "must-pass legislation," such as an appropriations bill, early in the upcoming session of Congress (Wodele 2004). The leadership thus took the first step toward repeal of the more collaborative driver's license provisions of the Intelligence Reform and Terrorism Prevention Act of 2004 and passage of the more prescriptive provisions of the REAL ID Act of 2005. 


\section{Second Post-9/11}

\section{Congressional Attempt to}

\section{Regulate the Driver's}

\section{LICENSE}

On January 26, 2005, just six weeks after the Intelligence Reform and Terrorism Act became law, Rep. Sensenbrenner introduced his immigration provisions in the House as the REAL ID Act (H.R. 418). The name of the act reflects Rep. Sensenbrenner's determination that "American citizens...know who is in their country, that people are who they say they are, and that the name on the driver's license is the real holder's name, not some alias" (2005a, H 454).

The White House announced its support of the REAL ID Act in a February 9, 2005 statement of administration policy (U.S. Office of Management 2005). Some commentators have suggested a motive for the Administration's decision to withdraw its support for the driver's license provisions of the Intelligence Reform and Terrorism Prevention Act in favor of those of the REAL ID Act: Rep. Sensenbrenner's power, as chairman of the House Judiciary Committee, to impede legislative progress on the President's proposal for a guest worker visa program (Dlouhy 2005a; Wald and Kirkpatrick 2005).

Rep. Sensenbrenner underscored his commitment to the driver's license provisions of the REAL ID Act by reminding his colleagues of the consequences of an inadequate system for issuing personal identification documents:

Mohammed Atta...entered the United States on a six-month visa. That visa expired on July 9,2001 . He got a driver's license from the State of Florida on May 5, 2001. That was a six-year driver's license. Had this bill been in effect at the time, that driver's license would have expired on July 9, and he would not have been able to use that driver's license to get on a plane because it was an expired ID (Sensenbrenner 2005b, H 460).

Several co-sponsors of the REAL ID Act also spoke to their determination to see its driver's license provisions replace those of the Intelligence Reform and Terrotism Prevention Act. Representative Tom Davis (R-VA), chairman of the House Government Reform Committee, asserted that the Intelligence Reform and Terrorism Prevention Act driver's license language "was filled with so many loopholes and optout clauses for states that it really only made matters worse" (2005, H 461). House Intelligence Committee chairman Peter Hoekstra (R-MI) observed that the Intelligence Reform and Terrorism Prevention Act provided "no hard date for implementation" of its driver's license standards and no certitude that the negotiated rulemaking process would "be concluded by the date specified in the act" (2005, $\mathrm{H}$ 470). In contrast, according to the act's sponsors, the REAL ID Act would "rapidly implement regulations for State driver's license and identification document security standards" (Bill 2005a). The REAL ID Act had 138 additional co-sponsors, all but two of whom were Republicans and almost half of whom were members of the Congressional Immigration Reform Caucus (Bill 2005a).

The House Republican leadership exercised firm control over legislative action on the REAL ID Act, in order: to fulfill its December 2004 pledge to attach the act to must-pass legislation early in the $109^{\text {th }}$ Congress. It employed restrictive rules, which have been used with increasing frequency over the past several decades to give the majority party in Congress control over the legislative process and legislative outcomes (Satumo and Bach 2004, CRS-2). The leadership restricted amendments to the REAL ID Act to five, one of which passed the House on February 10 by voice vote and provided that information on individuals convicted of using a false driver's license or identity card while attempting to board an airplane be entered into the appropriate aviation security screening database (U.S. Congress House 2005a, H 544). ${ }^{4}$ The leadership also limited debate on the House floor, which was held on February 9 and 10 , to 100 minutes. ${ }^{5}$

The House Republican leadership also drew upon what Hacker and Pierson have described as "the unmatched coordination and cohesion of ruling Republicans" (2005, 3). These attributes of the Republican majority allow the leadership to ensure that the House debates huge and highly conservative pieces of legislation in a 
matter of hours, without any formal input from Democrats, without serious consideration of competing issues, and without any real prospect of defeat or amendment on the House floor (Hacker and Pierson 2005, 78).

Indeed, the House Judiciary, Homeland Security, and Government Reform Committees, to which the REAL ID Act was referred, neither held hearings not issued reports (Bill 2005a; H.R. 418 2005).

On February 10, the House passed the REAL ID Act by a vote of 261-161 (U.S. Congress House 2005a, H 544). One month later, the House took two further votes that moved Rep. Sensenbrenner closer to his goal of supplanting the driver's license provisions of the Intelligence Reform and Terrorism Prevention Act with the more prescriptive driver's license provisions of the REAL ID Act (U.S. Congress House 2005g, H 1525). On March 15, the House Republican leadership, as promised, engineered passage of a House rule, by a close vote of 220-195, that attached the REAL ID Act to the Emergency Supplemental Appropriations Act for Defense, the Global War on Terror, and Tsunami Relief, 2005 (H.R. 1268). ${ }^{6}$ The must-pass nature of this emergency supplemental appropriations measure is indicated by Defense Secretary Donald Rumsfeld's warning to the Senate Appropriations Committee that without it "some military commands might have to stop hiring personnel, ordering supplies or awarding contracts [and]... the Pentagon may have to invoke the Feed and Forage Act" (Plummer 2005, 1156). Clearly, no matter how objectionable members of Congress found the REAL ID Act driver's license provisions, they could not fail to vote in favor of the measure. Indeed, on March 16, the emergency supplemental-with the REAL ID Act provisions attached-passed the House easily by a vote of 38843 (U.S. Congress House 2005g, H 1525).

The Senate turned to a consideration of the REAL ID Act on April 6. Although debate in the Senate was longer than in the House-two weeks tather than two days-many senators objected that, Fike their colleagues in the House, they had been given insufficient opportunity to voice their concerns about the REAL ID Act. The objection of Senator Robert Byrd (DWV) is illustrative:
Neither the majority nor the minority of the Senate Appropriations Committee participated in the formulation of the REAL ID immigration provisions. These REAL ID provisions were formulated behind closed doors by the House and Senate Republican leadership.... It was simply grafted onto the emergency supplemental appropriations bill (2005, S 4820).

Senators also expressed concern about the REAL ID Act's erosion of state sovereignty. Senator Dianne Feinstein (D-CA) observed that "the REAL ID Act essentially countermands the rights of the States.... The REAL ID Act imposes on States what must be done" (2005, S 3541). Senators from both parties opposed the act and, when the emergency supplemental appropriations measure passed the Senate on April 21 by a vote of 99-0, it did not contain the REAL ID Act driver's license provisions (Bill 2005b; U.S. Congress Senate 2005a, S 4093).

Congress convened a conference committee on April 27 and 28 to reconcile the House and Senate versions of the emergency supplemental appropriations measure. The tone of the conference committee's deliberations reflected that of earlier legislative action on the REAL ID Act. Representative John Conyers, Jr. (D-MD), ranking Democrat on the House Judiciary Committee, charged that "Democrats were shut out of all negotiations in conference and none of our concerns were addressed" (Stern 2005b). Echoing observations made by Sen. Byrd and others, he asserted that Congress adopted the REAL ID Act provisions "without hearings, review, negotiation or debate" (Stern 2005b).

The conference report, filed on May 3, 2005, included almost all of the driver's license provisions of the REAL ID Act (U.S. Congress House 2005b). Conferees made two noteworthy modifications, however: States were released from a mandate to share driver's data with Canada and Mexico and were authorized to issue, in addition to the higher level driver's license for those who could prove citizenship or legal residency, a lower level certificate of driving for those who could not (Stern 2005a; Stern 2005c).

The success of the House Republican leadership's "must-pass" strategy, which relied on the reluctance 
of members of Congress to block a bill appropriating funds for troops overseas, was reflected in the final votes on the emergency supplemental appropriations measure. On May 5, the House agreed to the conference report by a vote of 368-58 and on May 10 , the Senate agreed by a vote of 100-0 (U.S. Congress House 2005h, H 3027; U.S. Congress Senate 2005b, S 4848). With the President's signature on May 11, 2005, the Emergency Supplemental Appropriations Act for Defense, the Global War on Terror, and Tsunami Relief, 2005-with the REAL ID Act driver's license provisions attached-became law and the driver's license provisions of the Intelligence Reform and Terrorism Prevention Act of 2004 were repealed.

\section{THE REAL ID ACT's}

\section{IMPACT ON STATES AND}

\section{LOCALITIES}

Critics of the REAI ID Act driver's license provisions object not only to the process by which they were enacted into law, but also to their impact. Federalism advocates, for example, charge that the provisions impinge on state sovereignty. Representative Sheila Jackson-Lee (D-TX) has called the REAL ID Act "an assault on federalism" and Representative Ron Paul (D-TX) has argued that "federally imposed standards for driver's licenses and birth certificates make a mockery of federalism and the $10^{\text {th }}$ Amendment" (2005, H 438; For 2005, 7).

Rep. Paul believes that the REAL ID Act "transforms state motor vehicle departments into agents of the federal government" (For 2005, 7). The scholarship of federalism lends credence to his charge. Kettl has noted "the growing importance of state and local governments as administrative agents of national programs" $(2004,113)$. "Administrative federalism" is the phrase he employs to describe this phenomenon, by which the federal government leverages "the activity of state and local governments to do much of its work" $(2004,113)$.

For a legislative body tackling the challenge of developing a secure system of personal identification, administrative federalism has powerful appeal. It allows Congress to limit the burden it places on a shrinking federal bureauctacy, control costs on the federal level during a period of significant budget deficits, and obscure its role in developing what some citizens consider a national ID. Kernell and Jacobson explain the incentives of administrative federalism in this way:

When members of Congress pass a law that obliges the states to provide particular services, they are yielding to a temptation all politicians share: the desire to respond to some citizens' demands without imposing costs on others. In forcing the states to pay for a program, members are imposing costs for which they will not be held accountable $(2003,97)$.

The costs imposed by the driver's license provision of the REAL ID Act are both figurative and literal. The figurative cost takes the form of preemptions of state authority. The Congressional Budget Office has identified four preemptions of state authority in the REAL ID Act, stemming from its requirements for uniform license design, valid identification documents, mandatory license expiration date, and resolution of discrepancies in social security numbers (U.S. Congress Congressional Budget 2005). Such preemptions are likely to displace state policy goals. State government officials fear, for example, that requiring proof of lawful presence in the United States will undermine their efforts to ensure public safety on the highways. They believe that a large group of unlicensed, uninsured motorists who do not know the tules of the road will increase the number of accidents and strain emergency services (Smith 2005, CRS-1). Their concern is wellfounded. The American Automobile Association Foundation for Traffic Safety has determined that "unlicensed drivers are almost five times more likely to be in fatal car accidents than are validly licensed drivers" (Roybal-Allard 2005, H 560).

In its 1996 draft report on federal mandates, the Advisory Commission on Intergovernmental Relations categorized mandates by whether there exists "a sufficient national interest to justify inttuding on state and local government abilities to control their own affairs" (U.S. Advisory 1996, 291). Cheye Calvo, the National Conference of State Legislatures' transportation director, has described the REAL ID 
Act as "a nightmare federal mandate that threatens to overwhelm state DMVs [departments of motor vehicles] with rigid, bureaucratic, and costly rules" (REAL 2005). Rep. Davis, on the other hand, has asserted that the act's driver's license provisions address "a national security issue that requires a unified national response rather than 50 separate responses" (2005, H 461). One could argue that national security is a sufficient national interest for the preemptive mandates in the REAL ID Act. Nevertheless, even justifiable preemptions create "a gradual erosion of state power in the federal system," as Perlman has noted (1994, 150).

States may, of course, ignore the driver's license provisions of the REAL ID Act, which apply only to licenses that will be used for federal identification purposes. However, any individual who expects to board an airplane, enter a federally-protected building, buy firearms, serve on a jury, register to vote, collect Social Security and veterans benefits, or use other federal government services will want an ID that conforms to the driver's license standards of the REAL ID Act. The states, in reality, must implement the standards. As Kettl has observed about administrative and fiscal federalism, "the states usually have discretion about whether to enlist as national agents, but the construction of the progtams typically leaves them little choice" $(2004,113)$.

The literal cost imposed by the driver's license provisions of the REAL ID Act takes the form of an unfunded mandate. The Congressional Budget Office has identified several "intergovernmental mandates" in the REAL ID Act, although it notes that the costs to the states imposed by the act are within the allowable threshold established by the Unfunded Mandates Reform Act of 1995 (U.S. Congress Congressional Budget 2005). The size of the mandate, however, is in dispute. The Congressional Budget Office has estimated a cost of implementation of $\$ 120$ million over five years (U.S. Congress Congressional Budget 2005). The National Conference of State Legislatures (NCSL), National Governors Association (NGA), and American Association of Motor Vehicle Administrators (AAMVA), on the other hand, have estimated implementation costs of more than $\$ 11$ billion during the first five years (National Governors Association National 2006, 3). Congress has authorized the
Secretary of Homeland Security to make grants to the states. However, Rep. Davis has acknowledged that insufficient federal funds are available to cover the full cost to the states of implementing the driver's license provisions of the REAL ID Act (Grimes 2005).

In addition to fiscal burdens, the driver's license provisions of the REAL ID Act pose operational challenges to state and local governments. Perhaps the most serious of these is the requirement that states verify the validity of documents presented by driver's license applicants. Thousands of separate government entities, large and small, technologically sophisticated and unsophisticated, issue birth records. The NGA, NCSL, and AAMVA point out that the REAL ID Act imposes "technological standards and verification procedures on states, many of which are beyond the current capacity of even the federal government" (Lieberman 2005, S 4003). They note that "while the act contemplates the use of five national electronic systems to facilitate verification, currently only one of these systems is available on a nationwide basis" (National Governors Association National 2006, 3).

\section{IMPLEMENTING THE REAL ID \\ Act Through Rulemaking}

Given the constitutional issues and implementation problems raised by the driver's license provisions of the REAL ID Act, active stakeholder involvement would seem important to the success of their implementation. Unfortunately, the constricted opportunity for debate on the REAL ID Act in Congress is mirrored in the limited opportunity for stakeholder involvement in the rulemaking process.

The implementation stage in the life of a law is controlled by the degree of authority Congress delegates to the executive branch and the type of rulemaking it mandates. In the REAL ID Act, Congress limited its delegation of authority to the Secretary of Homeland Security by dictating driver's license standards in much greater detail than in the Intelligence Reform and Terrorism Prevention Act. In addition, Congress prohibited negotiated rulemaking and mandated nothing more than "a conventional 
regulatory notice procedure" (U.S. Congress Congressional Record 2005c, H 2876).

The requirements of conventional regulatory notice - that is, notice and comment rulemaking - are outlined in the Administrative Procedure Act of 1946. Under notice and comment rulemaking, also known as informal rulemaking, an agency announces its intention to develop regulations with a Notice of Proposed Rulemaking in the Federal Register, the federal government publication that provides official notice of all regulations affecting citizens. The agency invites comments on the proposed rule and may, if it chooses, provide for other forms of public participation in the development of the rule. The agency must be able to prove, if it is challenged in court, that it took stakeholder input into consideration when it wrote the final rule.

Kerwin has described notice and comment rulemaking as "a minimalist approach to public involvement" (2003, 165). Indeed, state homeland security directors appear to feel as excluded from the REAL ID Act rulemaking process as many members of Congress felt from the lawmaking process. The NGA Center for Best Practices reports that states do not feel they have any representation in the [Department of Homeland Security (DHS)] policy development and rulemaking process. Several homeland security directors noted DHS consults with a limited number of handpicked state officials and then claims to produce policy based on broad state input. Even when DHS does bring these selected homeland security directors into its processes, it often ignores their contributions (National Governors Association Center 2006, 5-6).

In the Intelligence Reform and Terrorism Prevention Act of 2004, Congress mandated that the Secretary of Transportation use negotiated rulemaking when developing driver's license standards. As its first step in the rulemaking process, an agency using negotiated rulemaking convenes a committee of stakeholders to develop a proposed rule. Representatives from relevant federal agencies and all groups substantially affected by the rule comprise the committee. The committee members work together, often with the assistance of an impartial facilitator, to reach consensus on the content of the rule. The agency may adopt the committee's proposed rule, develop a different rule, or choose not to issue a rule. If the agency decides to proceed with rulemaking, it follows the conventional notice and comment rulemaking process.

Negotiated rulemaking, also known as regulatory negotiation or reg neg, has two advantages that are particularly important when an agency develops rules to implement a policy as controversial as federal government standardization of the driver's license. First, stakeholders have an opportunity not only to provide written comments on a proposed rule, but also to actively shape its content before the written comment phase of the rulemaking process. Kerwin observes that reg neg "offers the public the most direct and influential tole in rulemaking of any reform of the process ever devised" $(2003,197)$. Second, the face-to-face negotiation that occurs in the first step of the negotiated rulemaking process makes this form of rulemaking less adversarial and more consensusbased than informal rulemaking (Harter 1982, 18). Participation and consensus lend a reg neg rule legitimacy, which facilitates the rule's implementation (Freeman and Langbein 2000; 63, 67). Hatter contends that "a regulation that is developed by and has the support of the respective interests would have a political legitimacy that regulations developed under any other process arguably lack" $(1982,7)$.

Negotiated rulemaking has disadvantages, however. Williams argues that reg neg "emphasizes the interests of individuals and interest groups more than those of the public at large," a concern sometimes referred to as "agency capture" (2000). Kerwin has observed that reg neg is expensive and that public participation can "complicate rulemaking and place the agency squarely between powerful contending forces" $(2003,160,201)$. Harter acknowledges that negotiation, used inappropriately, "could simply add another layer to the already protracted rulemaking process" $(1982,7)$. Congressional sponsors of the REAL ID Act, eager to develop a more secure system of personal identification as expeditiously as possible, may have had these disadvantages in mind when they mandated a less collaborative form of rulemaking. 
State and local government officials unequivocally prefer the legislative and rulemaking approach of the Intelligence Reform and Terrorism Prevention Act.. The NCSL, NGA, and AAMVA assert that

the driver's license and ID card provisions of the Intelligence Reform and Tertorism Prevention Act of 2004 offer the best course... [and] a workable framework for developing meaningful standards to increase reliability and security of driver's licenses and ID cards.... This framework calls for input from state elected officials and motor vehicle administrators in the regulatory process (Lieberman 2005, S 4003).

\section{The Future of Driver's}

\section{LiCENSE Standardization}

The still-unfolding history of the REAL ID Act supports former Senator Alan K. Simpson's contention that "no problem was ever more apparent than the susceptibility of federal, state, and local documents to fraud and misuse. And no problem was ever politically more difficult than trying to pass legislation to improve these documents" (U.S. Congress House 2002, 26). The NCSL has adopted a policy that calls for repeal of the REAL ID Act if Congress does not fully fund its implementation by December 31, 2007 (National Conference 2006). Mike Huckabee, governor of Arkansas and chairman of the NGA when the REAL ID Act became law, has warned that "if more than half of the governors agree, we're not going down without a fight on this. Congress will have to consider changing [the rules]" (Gamboa 2005).

It appears that Congress might do so. On December 8, 2006, Senator Daniel K. Akaka (D-HI) and Senator John E. Sununu (R-NH) introduced the Identification Security Enhancement Act (S. 4117), which calls for repeal of the REAL ID Act and reinstatement of the driver's license provisions of the Intelligence Reform and Terrorism Prevention Act of 2004 (U.S. Congress Congressional Record 2006). Sen. Akaka, who in 2007 will chair a subcommittee of the Senate's Committee on Flomeland Security and
Governmental Affairs, intends to pursue action on the bill if the Secretary of Homeland Security fails to issue workable regulations (U.S. Congress Congressional Record 2006).

Driver's license standardization is a contentious issue. Indeed, the driver's license provisions of the Illegal Immigration Reform and Immigrant Responsibility Act of 1996 provoked such a storm of criticism that they were repealed in Section 355 of the Department of Transportation and Related Agencies Appropriations Act of 2000 (Garcia, Lee, and Tatelman 2005, CRS-38). Will the driver's license provisions of the REAL ID Act share this fate? 'The continuing story of driver's license standardization encourages us to ponder an even larger question: Is a collaborative or a prescriptive approach to legislation and rulemaking more likely to provide the United States with a secure system for personal identification? Negotiating a policy, while time-consuming, may be more effective than imposing a policy. Ignoring dissenting views or circumventing them with parliamentary maneuvers does not make them go away. Indeed, the issue of state sovereignty provokes controversy today, as it did more than 200 years ago. The Federalist essays remind us of the importance Madison and Hamilton placed on negotiating with their fellow citizens over the issue. Pexhaps their approach should be ours.

\section{Notes}

1 The REAL ID Act of 2005 contains additional provisions that are intended to disrupt terrorist travel but that are unrelated to establishing personal identity. These provisions change the U.S. asylum system and U.S. laws governing deportation and facilitate completion of the San Diego Border Fence on the Mexico-U.S. border. Only the act's provisions regarding the driver's license are discussed in this article.

2 This provision of the law is an attempt to address the constitutional issues raised by driver's license standardization. The Congressional Research Service (CRS) observes: "It may be possible to argue that, because the issuance of drivers' licenses remains a state regulatory function, the minimum issuance and verification requirements established in this bill, even 
if limited to federal agency acceptance, constitute an effective commandeering by Congress of the state regulatory process, or a conscription of the state and local officials who issue the licenses" (Garcia, Lee, and Tatelman 2005, CRS-39). Commandeering the state regulatory process and conscripting state and local officials would be a violation of Supreme Court rulings in Nem York $\nu$. United States, 505 U.S. 144 (1992) and Printz v. United States, 521 U.S. 898, 935 (1997) (Garcia, Lee, and Tatelman 2005, CRS-39). The CRS has also argued, however, that Congress has the authority to pass legislation affecting the issuance of a driver's license to an illegal alien, given its "power to regulate immigration and commerce... ability to set conditions on the receipt of federal funds, and...discretion to set standards for identification documents that can be accepted for purposes of federal programs" (Smith 2005, CRS-2).

${ }^{3}$ Minimum standards for the driver's license are the subject of Section 7212, Subtitle B-Terrorist Travel and Effective Screening, Title VII-Implementation of $9 / 11$ Commission Recommendations of the Intelligence Reform and Terrorism Prevention Act of 2004.

${ }^{4}$ Rules Committee resolution H.R. Res. 75 restricted amendments to the five included in House Report 1094 (Bill 2005c; U.S. Congress House 2005d).

${ }^{5}$ Rules Committee resolution H.R. Res. 71 limited debate to 100 minutes (U.S. Congress House 2005c).

"House rule H.R. Res 151 attached the REAL ID Act to the Emergency Supplemental Appropriations Act for Defense, the Global War on Terror, and Tsunami Relief, 2005 (U.S. Congress House 2005f, H 1434). This must-pass emergency supplemental measure had been reported four days earlier from the House Committee on Appropriations by Representative Jerry Lewis (R-California) (U.S. Congress Congressional Record 2005a, H 1416).

${ }^{7}$ Senator Thad Cochran (R-MS) reported the Senate's version of the emergency supplemental appropriations bill (H.R. 1268) from the Senate Committee on
Appropriations on April 6, 2005 (U.S. Congress Congressional Record 2005b, S 3277).

\section{REFERENCES}

Bill Summaty and Status for the $109^{\text {th }}$ Congress: H.R. 418. 2005a. Washington, DC: Library of Congress, Legislative Information Service.

Bill Summary and Status for the $109^{\text {th }}$ Congress: H.R. 1268. 2005b. Washington, DC: Library of Congress, Legislative Information Service.

Bill Summary and Status for the $109^{\text {th }}$ Congress: H.R. Res. 75. 2005c. Washington, DC: Library of Congress, Legislative Information Service.

Byrd, Senator Robert. 2005. Remarks in the Senate regarding the REAL ID Act provisions of H.R. $1268,109^{\text {th }}$ Cong., $1^{\text {st }}$ sess. Congressional Record (May 10): S $4820-S 4821$. From the Congressional Record Online via GPO (http:// www:gpoaccess.gov/crecord/index.html) at http:/ / frwebgate 3.access.gpo.gov/cgi-bin/ waisgate.cgi? WAISdocID $=3800317724+0+0+0 \&$ WAISaction=retrieve $($ accessed November 21 , 2005).

Civil Liberties Post-September 11, 2001. 2005. Electronic Privacy Information Center. Under Public Opinion on Privacy-Introduction at www.epic,org/privacy/survey/default.html (last updated October 9, accessed November 18, 2005).

Clyne, Meghan. 2005. Roots of REAL ID Act Reach to Post-September 11 New York. The Nem York Sun (May 6). From LexisNexis A cademic Universe via George Washington University's ALADIN Research Portal at http://web.lexisnexis.com.proxygw.wrlc.org/universe/document? _m $=433$ a1403ecbbecd6a6dcb68fb1b6bd $92 \&$ - d o c n u m $=1 \&$ w c h p $=$ d G L b V z z zSkVA\&_md5 $=8$ e68da40d1184b508337b d51f05e61ff (accessed October 14, 2005). 
Davis, Representative Tom. 2005. Remarks in the House of Representatives regarding the REAL ID Att, H.R. 418, $109^{\text {th }}$ Cong., ${ }^{\text {st }}$ sess. Congressional Record (February 9): $\mathrm{H} 460-\mathrm{H}$ 461. From the Congressional Record Online via GPO (http:// www.gpoaccess.gov/crecord/index.html) at http://frwebgate1.access.gpo.gov/cgi-bin/ wa is gate.cgi? W A I S d o c I D $=375921241863+0+0+0 \&$ WAISaction=retrieve (accessed October 15, 2005).

Dlouhy, Jennifer A. 2005a. Bush Signals Support for Sensenbrenner Bill in Bid for Momentum on Guest Workers. CQ Today (February 9). From CQ.com on Congress via George Washington University's ALADIN Research Portal at http:// oncongress.cq.com.proxygw.wrlc.org/ display.do?dockey $=/$ cqonline $/ \mathrm{prod} / \mathrm{data} / \mathrm{docs} /$ h t m $1 /$ n ew s/ $109 / \mathrm{news} 109$ 000001525220.html@allnews\&metapub=CQNEWS\&searchIndex $=6 \&$ seqNum $=1$ (accessed October 24, 2005).

2005b. Sensenbrenner to Get His Day on Immigration, but Issues Are Far From Settled. $C Q$ Today (February 4). From CQ.com on Congress via George Washington University's ALADIN Research Portal at http://oncongress.cq.com. proxygw.wrlc.org/display.dordockey=/cqonline/ prod/data/docs/html/news/109/news109000001519010.html@allnews\&metapub=CQNEWS\&searchIndex $=0 \&$ seq Num $=1$ (accessed November 1, 2005).

Feinstein, Senator Dianne. 2005. Remarks in the Senate regarding the REAI ID Act provisions of H.R. $1268,109^{\text {th }}$ Cong, $1^{\text {st }}$ sess. Congressional Record (April 13): S 3540 - S 3541. From the Congressional Record Online via GPO (http:// www.gpoaccess.gov/crecord/index.html) at http://frwebgate2.access.gpo.gov/cgi-bin/ waisgate.cgi? WAISdocID $=377564508163$ +0+0+0\&WAISaction=retrieve (accessed November 21, 2005).

For Failing to Protect Our Borders, We Are Now Less Free. 2005. The New American, 21 (12): 7. From
ProQuest Research Library Plus via George Washington University's ALADIN Research Portal at http://proquest.umi.com.proxygw.wilc.org/ pqdweb?index $=0 \& \mathrm{did}=857302921 \&$ SrchMode $=$ $1 \&$ sid $=1 \& F m t=3 \& V I n s t=$ PROD $\& V T y p e=P Q D$ $\& \mathrm{RQT}=309 \& \mathrm{VName}=\mathrm{PQD} \& \mathrm{~T}^{\prime} \mathrm{T}=1133377035$ \&clientId=31812 (accessed October 14, 2005).

Freeman, Jody and Laura I. Langbein. 2000. Regulatory Negotiation and the Legitimacy Benefit. N.Y.U. Environmental Law Journal 9:60-151. From wwwlaw.nyu.edu/journals/envtllaw/issues/vol9/ 1/v9n1a3.pdf (accessed 12/3/2006).

Gamboa, Suzanne. 2005. Senator Joins Democrats in Criticizing Driver's License Rules. The Associated Press State fo Local Wire (May 11). From LexisNexis Academic Universe via George Washington University's ALADIN Research Portal at http:// web.lexis-nexis.com.proxygw.wrlc.org/universe/ document?_m=01539fe $9 \mathrm{c} 27 \mathrm{~d} 381 \mathrm{c} 86911$ $7536199468 \mathrm{~d} \&$ _docnum $=1 \& \mathrm{wchp}=\mathrm{dGLbVtz}-$

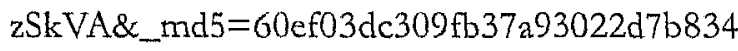
95d9b (accessed October 15, 2005).

Garcia, Michael John, Margaret Mikyung Lee, and Todd Tatelman. 2005. Immigration: Analysis of the Provisions of the REAL ID Act of 2005. U.S. Congress, Congressional Research Service. CRS Report for Congress no. RL32754, updated May 25.

Garfinkel, Simson. 2000. Database Nation: The Death of Privacy in the $21^{\text {st }}$ Century. Sebastopol, CA: O'Reilly.

Grimes, Brad. 2005. Davis Bristles at Characterization of REAL ID Act as Unfunded Mandate. PostNensweek Business Information Inc. Newsbytes (September 14). From LexisNexis Academic Universe via George Washington University's ALADIN Research Portal at http://web.lexisnexis.com.proxygw.wrlc.org/universe/document? _m=acebfefcb $574 \mathrm{e} 2 \mathrm{edfa} 59 \mathrm{f} 9 \mathrm{~d} 20 \mathrm{a} 2 \mathrm{e} 70 \mathrm{eb}$ \&_docnum $=1 \& w c h p=d G L b V t z-z S k V A \&$ $\mathrm{md} 5=62 \mathrm{e} 37 \mathrm{adf} 43 \mathrm{~d} 882 \mathrm{fd} 2 \mathrm{c} 543 \mathrm{c} 2 \mathrm{e} 7 \mathrm{bf0b} 75 \mathrm{e}$ ) (accessed October 15, 2005). 
Grow, Brian. 2003. Licenses to Kill. Business Week (May 5): 71 .

Hacker, Jacob and Paul Pierson. 2005. Off Center: The Republican Revolution and the Erosion of American Democray. New Haven: Yale University Press.

Hamilton, Alexander, John Jay and James Madison. 2001. The Federalist. The Gideon Edition, George W. Carey and James McClellan, eds. Indianapolis: Liberty Fund.

Harter, Philip J. 1982. Negotiating Regulations: A Cure for Malaise. The Georgetonn Law Journal 71:1-118.

Hoekstra, Representative Peter. 2005. Remarks in the House of Representatives regarding the REAL ID Act, H.R. 418, 109 $9^{\text {th }}$ Cong., $1^{\text {st }}$ sess. Congressional Record (February 9): $\mathrm{H} 470-\mathrm{H} 471$. From the Congressional Record Online via GPO (http:// www.gpoaccess.gov/crecord/index.html) at http://frwebgate1.access.gpo.gov/cgi-bin/ w a is g a t e.c g i ? W A I S o c I D $=375921241863+0+0+0 \&$ WAISaction=retrieve (accessed October 15, 2005).

H.R. 10 (9/11 Recommendations Implementation Act) and S. 2845 (National Intelligence Reform Act of 2004): A Comparative Analysis. 2004. U.S. Congress, Congressional Research Service. CRS Report for Congress no. RL32635, updated October 21.

Jackson-Lee, Representative Sheila. 2005. Remarks in the House of Representatives regarding the REAL ID Act, H.R. 418, $109^{\text {th }}$ Cong., $1^{\text {st }}$ sess. Congressional Record (February 9): H $437-\mathrm{H}$ 438. From the Congressional Recotd Online via GPO (http:// www.gpoaccess.gov/crecord/index.html) at http://frwebgate1.access.gpo.gov/cgi-bin/ wa is gate.cgi ? W A I d o c I D = $366416208757+0+0+0 \&$ WAISaction $=$ retrieve (accessed October 24, 2005).

Kady II, Martin. 2004. Intelligence Overhaul's Fate Still Mired in Turf Disputes. CQ Weekly Online (November 20): 2746-2748. At http:// library.cqpress.com/cqweekly/weeklyreport108000001430585 (accessed January 3, 2007).

Kernell, Samuel and Gary C. Jacobson. 2003. The Logic of American Politics. Washington, DC: CQ Press.

Kerwin, Cornelius M. 2003. Rulemaking: How Government Agencies Write Law and Make Policy. Washington, DC: CQ Press.

Kettl, Donald F. 2004. Federalism: Battles on the Front Lines of Public Policy. In Principles and Practice of American Politics: Classic and Contemporary Readings $2^{\text {nd }}$ ed., edited by Samuel Kernell and Steven S. Smith, 102-117. Washington, DC: CQ Press.

Lieberman, Senator Joe. 2005. Remarks in the Senate regarding the REAL ID Act provisions of H.R. S Online via GPO (http://www.gpoaccess.gov/ crecord/index.html) at http:// frwebgate 1.access.gpo.gov/cgi-bin/ waisgate.cgi?WAISdocID $=378488199517+0+0+0 \&$ WAISaction=retrieve) (accessed November 23, 2005).

National Commission on Terrorist Attacks Upon the United States. 2004. The 9/11 Commission Report: Final Report of the National Commission on Terrorist Attacks Upon the United States. Authorized ed. New York: W.W. Norton.

National Conference of State Legislatures. 2006. 20062007 Policies for the Jurisdiction of the Transportation Committee: Implementation of the REAL ID. www.ncsl.org/statefed/ transportation.htm (accessed September 20, 2006).

National Governors Association Center for Best Practices. 2006. 2006 State Homeland Security Directors Survey: New Challenges, Changing Relationships. April 3. www.nga.org/Files/pdf/ 0604HLSDIRSURVEY.pdf (accessed September 20, 2006).

National Governors Association, National Conference of State Legislatures, and American Association of Motor Vehicle Administrators. 2006. The Real. 
ID Act: National Impact Analysis. September. www.ncsl.org/print/statefed/ Real_ID_Impact_Report_FINAL_Sept19.pdf (accessed September 25, 2006).

Newsmaker Transcripts-Congressional Events. 2005. Reps. Sensenbrenner, Hunter, and Dreier Hold News Conference, CQ.com (May 4). From CQ.com on Congress via George Washington University's ALADIN Research Portal at http:// oncongress.cq.com.proxygw.wrlc.org/ display.do?dockey $=/$ cqonline/prod/data/docs/ $\mathrm{html} / \mathrm{transcripts/newsmaker/109/}$ new s makertrans cripts $109-$ 000001657372.html@committees\&metapub=CQTRANSCRIPTS (accessed October 15, 2005).

Perlman, Ellen, 1994. The Preemption Beast: The Gorilla That Swallows State Laws. Governing (August): 46-51. Reptinted in American Intergovernmental Relations: Foundations, Perspectives, and Issues $3^{\text {rd }}$ ed. 2000, edited by Laurence J. O'Toole, Jr., 143-151, Washington, DC: CQ Press.

Plummer, Anne. 2005. Senate Provisions Tie Up Supplemental, CQ Weekly (May 2): 1156.

Putrich, Gayle S. 2005. CQ Bill Analysis, H.R. 1268. From CQ.com on Congress via George Washington University's ALADIN Research Portal at http://oncongress.cq.com.proxygw.wrlc.org/ display.do?dockey $=/ \mathrm{cqonline} / \mathrm{prod} /$ data/docs / html/billwatch/109/billwatch 109 . 000001526451.html@allbills\&metapub=CQBILLWWTCH\&fL=1 (accessed October 14, 2005).

REAL ID Will Place a Huge Economic Burden on States. 2005. All Tbings Considered, National Public Radio (May 13). From ProQuest Research Library Plus via George Washington University's ALADIN Research Portal at http:// proquest.umi.com.proxygw.wrlc.org/ pqdweb? index $=0 \&$ did $=839861241$ \&SrchMode $=1 \&$ sid $=1 \&$ Fmt $=3 \&$ VInst $=$ PROD \& VType=PQD\&RQI $=309 \& V \mathrm{Name}=\mathrm{PQD} \& \mathrm{TS}=1133378776$ \&clientId=31812 (accessed October 14, 2005).
Roybal-Allard, Representative Lucille. 2005. Remarks in the House of Representatives regarding the REAL ID Act, H.R. 418, $109^{\text {th }}$. Cong., $1^{\text {st }}$ sess. Congressional Record, February 10, H 560. From the Congressional Record Online via GPO (http:// www.gpoaccess.gov/crecord/index.html) at http://frwebgate4.access.gpo.gov/cgi-bin/ wa is gate.cgi? W A I d oc I D = $37964629958+0+0+0 \&$ WAISaction $=$ retrieve) (accessed October 19, 2005).

Saturno, James V. and Stanley Bach. 2004. House Rules Committee Hearings on Special Rules. U.S. Congress, Congressional Research Service. CRS Report for Congress no. 98-313GOV, updated November 19.

Sensenbrenner, Representative F. James, Jr. 2004. Remarks in the House of Representatives regarding the REAL ID Act, H.R. 10, 108 ${ }^{\text {th }}$ Cong., $2^{\text {nd }}$ sess. Congressional Record, (December 7): H $10998-\mathrm{H}$ 10999. From the Congressional Record Online via GPO (http://www.gpoaccess.gov/crecord/ index.html) at http:/ / frwebgate2.access.gpo.gov/ cgi-bin/waisgate.cgi? WAISdocID = $375506498361+0+0+0 \&$ WAISaction $=$ retrieve (accessed October 12, 2005). Representatives regarding the REALID Act, H.R. 418, $109^{\text {th }}$ Cong., $1^{\text {st }}$ sess. Congressional Record (February 9): $\mathrm{H}$ 454. From the Congressional Record Online via GPO (http:// www.gpoaccess.gov/crecord/index.html) at http://frwebgate4.access.gpo.gov/cgi-bin/ waisgate.cgi? WAISdocID $=3644635273$ $+1+0+0 \& W A I S a c t i o n=$ retricve (accessed October 24, 2005).

bemarks in the Representatives regarding the REAL ID Act, H.R. $418,109^{\text {th }}$ Cong., $1^{\text {st }}$ sess. Congressional Record (February 9): H 460. From the Congressional Record Online via GPO (http:// www.gpoaccess.gov/crecord/index.html) at http://frwebgate1,access.gpo.gov/cgi-bin/ waisgate.cgi? WAISdocID $=375921241863$ 
$+0+0+0 \& W A I S a c t i o n=$ retrieve $\quad$ accessed October 24, 2005).

Smith, Alison M. 2005. Summary of State Laws on the Issuance of Driver's Licenses to Undocumented Aliens. U.S. Congress, Congtessional Research Service. CRS Report for Congress no. RL32127, updated September 13.

Stern, Seth. 2005a. Details of New Immigration Law. CQ Weekly (July 11): 1908.

2005b. Sensenbrenner Gets Immigration Provision; Senate Forces Some Changes. CQ Today (May 3). From CQ.com on Congress vin George Washington University's ALADIN Research Portal at http://oncongress.cq.com.proxygw.wrlc.org/ display.dordockey $=/$ cqonline $/ \mathrm{prod} /$ data/docs/ $\mathrm{htm} \mathrm{l/n} \mathrm{ew} \mathrm{s/} 109 / \mathrm{ne}$ w 109 000001661832.html@allnews\&metapub=CQNEWS\&searchIndex $=13 \&$ seqNum=1) (accessed October 20, 2005).

. 2005c. Sensenbrenner's Win on Immigration. CQ Weekly (May 9): 1241.

Tancredo, Representative Tom. 2004. Remarks in the House of Representatives regarding the REAL ID Act, H.R. 10, $108^{\text {th }}$ Cong., $2^{\text {nd }}$ sess. Congressional Record (December 7): H 11004 - H 11005. From the Congressional Record Online via GPO (http:/ /www.gpoaccess.gov/crecord/index.html) at http://frwebgate4.access.gpo.gov/cgi-bin/ waisgate.cgi? WAIS docID $=3733366522$ $+0+0+0 \& W A I S a c t i o n=$ retrieve (accessed October 15, 2005).

Tatelman, Todd B. 2005. Intelligence Reform and Terrotism Prevention Act of 2004: National Standards for Driver's Licenses, Social Security Cards, and Birth Certificates. U.S. Congress, Congressional Research Service. CRS Report for Congress no. RL32722, dated January 6.

U.S. Advisory Commission on Intergovernmental Relations. 1996. The Role of Federal Mandates in Intergovernmental Relations: Draft Report. Washington,
DC: ACIR. Excerpts reprinted in American Intergovernmental Relations: Foundations, Perspectives, and Isstes $3^{\text {rd }}$ ed. 2000, edited by Laurence J. O'Toole, Jr., 285-295, Washington, DC: CQ Press.

U.S, Congress. Congressional Budget Office. 2005. Cost Estimate: H.R. 418, REAL ID Act of 2005 as Introduced on January 26, 2005. February 9. $\mathrm{w}$ w w. $\mathrm{c}$ b 0 . $\mathrm{g} \circ \mathrm{v} /$ showdoc.cfm?index $=6072 \&$ sequence $=0 \&$ from $=6$ (accessed October 14, 2005).

U.S. Congress. Congressional Record. 2005a. 109 ${ }^{\text {th }}$ Cong., $1^{\text {st }}$ sess. (March 14): H 1416. From the Congressional Record Online via GPO (http:// www.gpoaccess.gov/crecord/index.html) at http://frwebgate1.access.gpo.gov/cgi-bin/ wa is gate.c gi ? W A I S o c I D = $377205250874+1+0+0 \&$ WAISaction=retrieve (accessed November 12, 2005).

2005b, $109^{\text {th }}$ Cong., $1^{\text {st }}$ sess. (April 6): S 3277. From the Congressional Record Online via GPO (http://www.gpoaccess.gov/crecord/index.html) at http://frwebgate3.access.gpo.gov/cgi-bin/ waisgate.cgi? WAIS docID $=3797394634$ $+1+0+0 \& W A I S a c t i o n=$ retrieve (accessed November 12, 2005).

2005c. $109^{\text {th }}$ Cong., $1^{\text {st }}$ sess. (May 3): H 28132877. From the Congressional Record Online via GPO (http://www.gpoaccess.gov/crecord/ index.html) at http:// frwebgate5.access.gpo.gov/ cgi-bin/waisgate.cgi? WAISdocID $=879651198927+0+0+0 \&$ WAISaction=retrieve (accessed January 15, 2007).

2006. 109 $9^{\text {th }}$ Cong, $2^{\text {nd }}$ sess. (December 8): S11744 - S11746. From the Congressional Record Online via GPO (http://www.gpoaccess.gov/ crecord/index.html) at http:// frwebgate1.access.gpo.gov/cgi-bin/ w a is g a $\mathrm{e}$. c g i ? W A I S d o c I D $=877203250863+1+0+0 \&$ WAISaction=retrieve (accessed December 22, 2006). 
U.S. Congress. House. 2002. Committee on Government Reform. Does America Need a National Identifier? Hearing, $107^{\text {th }}$ Cong., $1^{\text {st }}$ sess., November 16, 2001. (Serial No. 107-118). Washington, DC: GPO.

2004. Roll No. 544, $108^{\text {th }}$ Cong,, $2^{\text {nd }}$ sess. Congressional Record (December 7): $\mathrm{H} 11028-\mathrm{H} 11029$. From the Congressional Record Online via GPO (http:// www.gpoaccess.gov/crecord/index.html) at http://frwebgate4.access.gpo.gov/cgi-bin/ waisgate.cgi? WAIS docID $=3740695134$ $+1+0+0 \& W A I S a c t i o n=$ retrieve (accessed October 20, 2005).

2005a. Amendment No. 2 to the REAL ID Act, H.R. 418, $109^{\text {th }}$ Cong, $1^{\text {st }}$ sess. Congressional Record (February 10): H 544. From the Congressional Record Online via GPO (http:// www.gpoaccess.gov/crecord/index.html) at http://frwebgate4.access.gpo.gov/cgi-bin/ waisgate,cgi? WAIS docID $=37684221368$ $+0+0+0 \& W A I S a c t i o n=$ retrieve (accessed October 22, 2005).

2005b. Emergency Supplemental Appropriations Act for Defense, the Global War on Terror; and Tsunami Relief Act, 2005. 109 ${ }^{\text {th }}$ Cong., ${ }^{\text {st }}$ sess., H. Rep. $109-$ 72. Congressional Record (May 3): H 2813-H 2877. From the Congressional Record Online via GPO (http://www.gpoaccess.gov/crecord/index.html) at http://frwebgate1.access.gpo.gov/cgi-bin/ waisgate.cgi? WAISdocID $=378041188649$ $+1+0+0 \& W A I S a c t i o n=r e t r i e v e)$ (accessed October 11, 2005).

2005c, Providing for Consideration of H.R. 418, REAL ID Act of 2005. $109^{\text {th }}$ Cong., $1^{\text {st }}$ sess., H.R. Res. 71. Congressional Record (February 9): $\mathrm{H} 437$. From the Congressional Record Online via GPO (http://www.gpoaccess.gov/crecord/index.html) at http://frwebgate1.access.gpo.gov/cgi-bin/ waisgate.cgi? WA ISdocID $=25628217822$ $+1+0+0 \& W A I S a c t i o n=$ retrieve (accessed February 6, 2006). 2005d. Providing for Furtber Consideration of $H . R$. 418, REAL ID Act of 2005. 109 ${ }^{\text {th }}$ Cong., $1^{\text {st }}$ sess., H.R. Res. 75. Congressional Record (February 10): H 527. From the Congressional Record Online via GPO (http://www.gpoaccess.gov/crecord/ index.html) at http://frwebgate1.access.gpo.gov/ cgi-bin/waisgate.cgi?WAISdocID $=256529217511$ $+17+0+0 \&$ WAISaction $=$ retrieve (accessed February 6, 2006).

2005e. Roll No. 31, $109^{\text {th }}$ Cong., $1^{\text {st }}$ sess. Congressional Record (February 10): H 566. From the Congressional Record Online via GPO (http://www.gpoaccess.gov/crecord/ index.html) at http://frwebgate4.access.gpo.gov/ cgi-bin/waisgate.cgi?WAISdocID $=37684221368$ $+0+0+0 \&$ WAISaction $=$ retrieve (accessed November 5, 2005).

2005f. Roll No. 69, $109^{\text {th }}$ Cong., $1^{\text {st }}$ sess. Congressional Record (March 15): H 1434-H 1435. From the Congressional Record Online via GPO (http://www.gpoaccess.gov/ crecord/index.html) at http:// frwebgate4.access.gpo.gov/cgi-bin/ waisgate.cgi? WAISdocID $=37718421686$ $+0+0+0 \& W A I S a c t i o n=$ retrieve (accessed November 11, 2005).

2005g. Roll No. 77, $109^{\text {th }}$ Cong., $1^{\text {st }}$ sess. Congressional Record (March 16): H $1525-H 1526$. From the Congressional Record Online via GPO (http://www.gpoaccess.gov/ crecord/index.html) at http:// frwebgate3.access.gpo.gov/cgi-bin/ waisgate.cgi? WAIS docID $=3796676221$ $+0+0+0 \& W A I S$ action $=$ retrieve (accessed November 11, 2005).

2005h. Roll No. 161, $109^{\text {th }}$ Cong., $1^{\text {st }}$ sess. Congressional Record (May 5): H 3027. From the Congressional Record Online via GPO (http:// www.gpoaccess.gov/crecord/index.html) at http://frwebgate4.access.gpo.gov/cgi-bin/ waisgate.cgi? WAIS docID $=37842330451$ $+3+0+0 \&$ WAISaction=retrieve) (accessed October 30, 2005). 
U.S. Congress. Senate. 2004. Rollcall Vote No. 216, $108^{\text {th }}$ Cong, $2^{\text {nd }}$ sess. Congressional Record (December 8): S 12010. From the Congressional Record Online via GPO (http://www.gpoaccess.gov/ crecord/index.html) at http:// frwebgate 5.access.gpo.gov/cgi-bin/ waisgate.cgi? WAISdocID $=373634231907$ $+0+0+0 \& W A I S a c t i o n=$ retrieve (accessed October 20, 2005).

2005a. Rollcall Vote No. 109, $109^{\text {th }}$ Cong., $1^{\text {st }}$ sess. Congressional Record (April 21): S 4093 - S 4094. From the Congressional Record Online via GPO (http://www.gpoaccess.gov/crecord/index.html) at http://frwebgate1.access.gpo.gov/cgi-bin/ waisgate.cgi?WAISdocID $=377976253803+0+0+0 \&$ WAISaction=retrieve) (accessed October 22, 2005).

2005b. Rollcall Vote No. 117, $109^{\text {th }}$ Cong., $1^{\text {st }}$ sess. Congressional Record (May 10): S $4848-S$ 4849. From the Congressional Record Online via GPO (http://www.gpoaccess.gov/crecord/ index.html) at http:/ frwebgate1.access.gpo.gov/ cgi-bin/waisgate.cgi? WAISdocID $=378395256394$ $+0+0+0 \&$ WAISaction $=$ retrieve) (accessed October 30, 2005).

U.S. Office of Homeland Security. 2002. The National Strategy for Homeland Security. Washington, DC: Office of Homeland Security.

U.S. Office of Management and Budget. 2005. Statement of Administration Policy, H.R. 418-REAL ID Act of 2005 (February 9). http:// www.whitehouse.gov/omb/legislative/sap/1091/hr418sap-h.pdf (accessed October 18, 2005).

Wald, Matthew L. and David D. Kirkpatrick. 2005. U.S. May Require Closer Scrutiny to Get a License. The Nens York Times, late edition, final (May 3). From LexisNexis Academic Universe via George Washington University's ALADIN Research Portal at http://web.lexis-nexis.com.proxygw.wrlc.org/ un i verse/document? - m $=c 732453 \mathrm{~d} 1 \mathrm{f} 5 \mathrm{~b} 0739086332 \mathrm{dd} 820581 \mathrm{c} 9$ \&_docnum $=1 \& \mathrm{wchp}=\mathrm{d}$ GLbVlb -
zSkVb\&_md5=1c8bc6eca41a66d16b74f1b532 bd6f98 (accessed October 15, 2005).

Williams, Juliet A. 2000. The Delegation Dilemma: Negotiated Rulemaking in Perspective. Policy Studies Review 17 (Spring). From Academic Search Premier via George Washington University's ALADIN Research Portal at http:// web.ebscohost.com.proxygw.wrlc.org/ehost/ detail?vid=8\&hid (accessed 12/4/2006).

Wodele, Greta. 2004. Intel Bill Heads to the House Floor Despite GOP Holdouts. CongressDaily (December 7). From Academic Search Premier via George Washington University's ALADIN Research Portal at http://search.epnet.com/ login.aspx?direct $=$ true $\& \mathrm{db}=\mathrm{aph} \& \mathrm{an}=15325762$ (accessed November 6, 2005). 
